\title{
Board of Directors and Export Activity under a Controlling Shareholder System: Evidence from Italy
}

\author{
Mario Ossorio \\ Assistant Professor of Management \\ Università degli Studi della Campania "Luigi Vanvitelli" \\ Corso Gran Priorato di Malta, 1, 81043, Capua(CE), Italy
}

\begin{abstract}
The decline of internal market and the increasing integration of different geographic areas has led firms to adopt internationalization strategies and defend their competitiveness. Using the agency view, this article sheds light on the relationship between firms' export activity and some attributes of board of directors (i.e., independent directors, CEO duality, and number of directors). Based on a sample of 115 Italian-listed firms, the results show that independent directors positively affect export activity, whereas board size negatively influences it.
\end{abstract}

Keywords: Internationalization, board of directors, independent directors, CEO duality, board size

\section{Introduction}

Exporting plays a relevant role for firms' growth because the expansion of activities into foreign countries represents a vital activity for their competitiveness (Johanson and Vahlne, 1977; 2009). While the increase in exports represents a consequence of a swiftly changing global environment (Alegre et al., 2012), it favors firms generating value-leveraging economies of scope (Aulakh et al., 2000). More generally, strengthening their international activities, firms defend themselves against global competitors, who, if left uncontrolled, may become stronger and represent a threat to the firm (Papadopoulos and Martìn, 2010). Furthermore, over the last years, the internal declining demand has been stimulating firms to exploit opportunities outside the domestic countries. Therefore, internationalization often has represented a strategy that, if not implemented, may jeopardize a firm's performance and competitiveness (George et al., 2005). Put differently, internationalization strategy affects the survival of firms.

Scholars point out that firms' internal resources and competences (e.g., managerial and technological skills, know-how, and information) are vital to adopt an effective internationalization process. Under these circumstances, board of directors represents an essential source of intangible and relational resources needed to support the internationalization process. While scholars have highlighted the role of top managers who possess competences and capabilities to face scrutiny for the dynamics of the firm's foreign markets (Herrmann and Datta, 2005; Nielsen, 2010), scant attention has been paid to the body of directors' role in the firm's internationalization process. Nevertheless, firms seemingly react to the international complexity through their governing bodies (Sanders and Carpenter, 1998). Scholars emphasize the importance of the board in formulating the corporate strategic orientation (Pugliese et al., 2009). In addition, "the character of companies in the coming years will be decided, in large measure, on how well boards can improve their own effectiveness" (Bird et al., 2004, p. 132). Although the board of directors play a crucial role in drafting and implementing the strategic decisions, such as those on internationalization, counselling management, and monitoring the consequences of these decisions (Haunschild, 1993), whether the board's characteristics affect the firm's internationalization degree remain an under-explored issue.

Using the agency framework (Jensen and Meckling, 1976), this article intends to fill the gap in the literature that analyzes the effect of some board's attributes (i.e., board independence, CEO duality, and board size) on a firm's internationalization degree. This is a very crucial issue when agency costs may emerge, at the expense of internationalization investment. Therefore, this article tries to answer the following question: Do board independence, CEO duality, and board size affect a firm's exports?

Regulators, academics, and business communities often point out both the advantages and disadvantages connected to the board's attributes. However empirical findings show that the effect of those attributes is still controversial. This article analyzes a sample of Italian-listed firms. The Italian context is an ideal setting because firms use pyramidal structures and a dual class of voting that generate conflicts between different categories of shareholders. Therefore, the board of directors may play an important role in conciliating divergent objectives. Empirical findings show that independent directors and board size significantly affect a firm's export activity. 
This article also shows two main contribution. The first contribution is to provide evidence on board of directors analysing an ownership system, characterized by majority shareholders that are able to control firms, despite their low fraction of cash flow rights. In fact, while most studies investigate the effect of corporate governance on strategic decisions that focus on fragmented ownership structures, this article analyzes a different ownership system where agency conflicts emerge between different shareholders categories. The second contribution is to shed light on the board's role in stimulating export activities, therefore, widening the antecedents of internationalization strategies.

The structure of this article is as follows: Section 2 contains a literature review that helps develop a set of hypotheses. Section 3 offers an empirical analysis, including a description of the sample and the definition of variables. Finally, Section 4 presents the discussion and concluding comments.

\section{Literature Review and Hypothesis Development}

\subsection{Corporate Board Theories}

Literature assigns several functions to the board of directors. Each function derives from a specific framework. The most largely used framework on this topic is agency theory, which has its roots in financial economics and represents one of the main pillars in the corporate governance literature. The work of Jensen and Meckling (1976) constitutes a seminal work and analyzes the interest conflicts generated by the separation of ownership and control in large companies. The agency relationship can be viewed as a contract where one party (i.e., the agent) makes an action on behalf of another party (i.e., the principal). Transferring this relationship to a public company framework, the principal and agent are the shareholders and the managers, respectively. Agency scholars point out that managers are encouraged to consume non-pecuniary personal benefits (perquisites), because they will take advantage entirely of those benefits while sustaining with the shareholders' relative costs. Under these circumstances, agency costs can emerge, and they are represented by monitoring costs (e.g., that linked to the use of board of directors and auditors), bonding costs (e.g., contractual limitations to managerial decision-making and golden parachutes), and residual loss. According to agency scholars, the decision-making process may be articulated in the following steps: 1) initiation, which is the generation of proposal for resource allocation; 2) ratification, which is the selection of the decision proposed by management; 3 ) implementation, which is the execution of chosen decisions; 4) monitoring, which is the valuation of the performance and the identification of rewards. Scholars indicate that managers should be in charge of formulating and implementing decisions, while directors should focus on ratifying and monitoring decisions (Fama and Jensen, 1983). Therefore, by an agency perspective, a relevant control function on the manager's activities is attributed to the board because of the manager's opportunistic behaviors and hidden actions.

Stewardship theory represents an alternative to the agency theory. More specifically, while the "model of man," depicted by agency theorists, is represented by individualistic, opportunistic, and self-serving managers, stewardship scholars view managers as individuals who are stimulated not only by nonfinancial motivations but also by a need to do a good job and to be a steward of the corporate assets (Donaldson and Davis, 1991). Consequently, a manager is motivated to gain intrinsic satisfaction through outstanding achievements at work. The manager's behavior is proorganizational and collectivistic; thus, he or she will place higher value on the firm's sales growth or profitability, because achieving these objectives, a steward's utility function is maximized (Davis et al., 1997). Under this perspective, monitoring CEO activities is not the main board function because the managers are trustworthy and act in a collectivistic way. The board should support and mentor the CEO. Therefore, directors could favor the decisionmaking process by providing competences, know-how, and soft skills - particularly to the CEO (Calabrò et al., 2013). Consequently, the board will mainly play an advisory function, with a focus on strategy (Machold et al., 2011; Pugliese et al., 2009).

The third theory is the resource dependence view, which considers a firm as an open system that has to acquire critical inputs (e.g., employees, technology, financial resources) to survive the external environment (Pfeffer and Salancick, 1978). "Criticality measures the ability of the organization to continue functioning in the absence of the resource or in the absence of the market for the output" (Pfeffer and Salancik, 1978, p. 46). Because of scarce resources, a firm's survival is not guaranteed, so the firm needs to establish relationships with the external environment to control the sources of critical inputs. Resource dependence theorists state that the main board tasks are connection and legitimacy. Including members of external organizations within its own board, a firm may connect itself with the external environment (Hillman and Dalziel, 2003). More specifically, through its cooptation strategies, the firm is favored to acquire external resources and may have the ability to effectively communicate information to its environment.

\subsection{Board of Directors and Internationalization: Hypotheses Development}

In recent years, an emerging strand of literature examined the relationship between board of directors and firms' degree of internationalization. In a sample of 562 board members from 45 listed Spanish companies, Barroso et al. (2011) 
show that board members' firm tenure, their experience in the firm's industry, their level of academic achievement, and their functional background tend to affect the decisions on the firm's degree of international diversification. In a study on 660 foreign market entries, involving acquisitions and joint ventures by United States (US) corporations, Lai et al. (2012) point out that the experience in foreign direct investment decisions of directors and their equity holdings stimulate the choice of the acquisition as the entry mode over a joint venture. Rivas (2012) analyzes a sample of the 108 largest European and US service and industrial firms by market capitalization and sheds light on the relationship between the diversity of boards and Top Management Team's to firm internationalization. Moreover, his study shows that functional background diversity of boards and younger boards age have a positive effect on internationalization. Based on agency and resource dependence theories (Jensen and Meckling, 1976; Pfeffer and Salancik, 1978), Chen et al. (2016) use data from a sample of 173 Taiwanese electronic firms and their findings indicate that independent directors' industry-specific experience, international experience, and interlocking directorate ties have a positive effect on internationalization and that an inverted-U relationship exists between independent directors' tenure overlap and internationalization.

In order to explore the relationship between the board of directors and a firm's internationalization degree through the agency perspective, it is useful to consider that agency conflicts between owners and managers in the Italian setting do not appear as a critical issue because majority shareholders are often top managers and have enough information to monitor managers (Munoz-Bullòn and Sanchez-Bueno, 2011). Nevertheless, agency problems can emerge between majority and minority shareholders. In fact, in Italy, controlling shareholders often adopt means such as pyramids, multiple classes of shares, and cross-holding to obtain a larger percentage of votes than that deriving by their fraction of cash flow rights (Faccio and Lang, 2002). These mechanisms can generate very relevant agency costs (Bigelli and Mengoli, 2004) because of non-aligned interests (Jensen and Meckling, 1976) and entrenchment (Fama and Jensen, 1983).

The divergence of cash flow and voting rights can lead majority shareholders to extract monetary and nonmonetary private benefits, since most of the connected costs are borne by minority shareholders. Private benefits may have different forms, for example: 1) "special dividends or (...) business relationships with the companies they control" (Shleifer and Vishny, 1997), 2) related party transactions, 3) empire building, 4) assignment of family members to management roles. The misallocation of resources allows the firm to maximize the welfare of majority shareholders at the expense of internationalization investments (Chen and Hsu, 2009).

Using the agency perspective (Fama and Jensen, 1983; Jensen and Meckling, 1976), the board could mitigate the agency problem, relative to underinvestment in internationalization activities. In fact, inside directors may be acquiescent to sub-optimal behaviors of top-managers because their careers depend on the latters' decisions. Consequently, the appointment of an adequate number of independent directors could guarantee a board's impartial behavior. Differently from inside directors, independent directors have no professional or labor relationships with the firm whose board they sit; therefore, they should perceive themselves free to monitor and judge the activity of topmanagers. They may request the substitution of top-managers if the latter are responsible for the firm's low performance. Consequently, the monitoring role of independent directors should represent a disciplinary mechanism to the top managers' opportunistic behaviors (Fama and Jensen, 1983). The control over management decisions implies that directors recall top managers to adopt internationalization strategies because they support the enduring competitive advantage. As shareholders benefit from promising internationalization programs, the board may stimulate internationalization investments through advising and monitoring activity. In addition, independent directors can be very beneficial because they bring valued competences, know-how, and expertise, which are very difficult to attain. When firms face complex investments, such as those on internationalization, external knowledge and experience represent essential assets (Faleye et al., 2011). According to the above discussion, the following hypothesis 1 (HI) is proposed:

\section{H1: Independent directors positively affect the firm's export activity.}

CEO duality represents the situation of the CEO who simultaneously is the chairperson of the board of directors. From an agency perspective, powerful CEOs may hamper or paralyze the board by filtering information and by planning the strategic agenda of board meetings (Kor, 2006). CEO duality may lead to conflicts of interests (Daily and Dalton, 1997; Goyal and Park, 2002) and, consequently, the Chairman/CEO would not have the adequate incentives to stimulate the board to play its monitoring activity. For example, he or she may select information flows to the board (Rutherford and Buchholtz, 2007), and generate a strong dependence of outside directors on inside ones. This condition may weaken the independence of the board, favoring opportunistic behaviors at expense of internationalization programs and, in turn, deteriorate the firm's performance (Aktas et al., 2018; Duru et al., 2016). 
CEO duality may expropriate minority shareholders, due to a lack of independence of the board. Consequently, controlling owners' objectives, that may differ from those of the other shareholders, may be favored, lowering the firm's long-term competitiveness (Baliga et al., 1996).

Therefore, separating the chairperson and CEO roles would lead to more efficient monitoring activity and limit managerial opportunism. Accordingly, a more independent board could more deeply investigate the CEO's policies and practices (Dalton et al., 2008) and stimulate value-maximizing investments (Krause and Semadeni, 2013), such as international expansion strategies. Literature points out a negative relationship between CEO duality and the likelihood of undertaking investments that increase long-term competitiveness (Chen and Hsu, 2009; Zona, 2016). According to the above discussion, the following hypothesis $2(H 2)$ is proposed:

H2: CEO duality negatively affects export activity.

The number of board directors (Lipton and Lorsch, 1992; Yermack, 1996) may generate different effects on internationalization strategies. Scholars emphasize that a greater number of directors permit the organization to possess heterogeneous competences, know-how, and information essential to fully analyze and comprehend expansion strategies into foreign markets (Haynes and Hillman, 2010; Zahra and Pearce, 1989). To effectively define internationalization strategies, firms need a wide set of competences, intangible resources, and expertise. Larger boards with a wider endowment of know-how and intangible skills (Goodstein et al., 1994) counsel organizations to more accurately handle high information-processing demands and propose outstanding and alternative solutions (Ruigrok et al., 2006), therefore, improving the effectiveness of international expansion strategies. Thus, the following hypothesis 3a $(H 3 a)$ is proposed:

H3a: Board size positively affects export activity.

Yet, a great number of directors could generate some distort behaviors within the board, such as fractionalization (Hackman, 2002), bitter cognitive conflicts, and different incompatible perspectives. The conflicts may get slow and hamper the reaching of a consensus on strategic decisions and cripple board working and, therefore, the CEO decisionmaking relative to internationalization projects. This is harmful for expansion strategies into foreign countries because such projects need a timely start and speedy advancement. A greater number of directors may generate the free-rider syndrome, social loafing, and high costs of coordination (Jensen, 1993).

Empirical evidence shows that board size negatively influences strategic activities, such as R\&D investments, accepting the hypotheses that larger boards lead to the generation of conflicts and difficulty in reaching consensus (Chen, 2012; Zona et al., 2011). Hence, the following hypothesis $3 \mathrm{~b}(H 3 b)$ is proposed:

H3b: Board size negatively affects export activity.

\section{Method}

\subsection{Sample}

Using a dataset of firms listed on the Italian Stock Exchange from 2010 to 2013, this article explores the relationships among board of directors and export intensity. Italian-listed companies represent the ideal setting for this study for several reasons. Firstly, the Italian stock market is featured by high stock concentration across firms (Bianco and Casavola, 1999), and families and state represent the two main controlling shareholders. Specifically, family ownership constitutes the most widespread form of control (Faccio and Lang, 2002). Nowadays the state and local authorities represent the second shareholder in terms of number of firms controlled and the first shareholder taking into account market capitalization of firms controlled (Consob, 2018). Majority shareholders use to assure the control of firms owned through cross-ownership, pyramids, and dual class of shares (La Porta et al., 2000).

The sample is constituted by Italian firms listed on the Milan Stock Exchange. To be included in the study sample, firms must preliminarily satisfy the following criteria: 1) firms operated in non-financial sectors, 2) firms continuously listed from 2010 to 2013, and 3) firms had a fiscal year-end of December 31. In addition, firms whose information on export was not available were excluded. Accordingly, the final sample consisted of 115 firms, and the number of observations is equal to 460 firm per year. The financial reporting data (including foreign sales, total sales, total debt, total assets, revenue, and $R \& D$ expenditure) are extracted from Data Stream Thomson Reuters. Data on family shareholding and board of directors are drawn from the Consob database.

\subsection{Definitions of Variables}

In this work, export intensity is the dependent variable; it is calculated as the ratio of sales in foreign countries to total sales. It is a very common definition in the literature on internationalization (Chen, 2011; Ruzzier and Antoncic, 2007) and expresses the relevance of international activities relative to total activities; therefore, it measures the firm's dependence on international markets (Barroso et al., 2011; Thomas and Eden, 2004). 
The ratio of independent directors serves as the independent variable and is obtained as the ratio between the number of independent directors and the total of directors within the same board. CEO duality is a binary variable, which equals the value of one (1) if the CEO is the Chairman of the board; otherwise, the value equals zero (0). Board size represents the number of directors sitting in a board.

A series of control variables has been included to control the effects of board of directors on the export intensity. Age, represented by the number of years separating the year of the observation to the year of foundation (Zahra, 2003), is controlled because the firm's age affects its ability to draw information about international activities and make up the architecture favoring the internationalization process (Chen, 2011). Leverage, calculated as total debt scaled by total assets, is controlled because the internationalization process requires the disposal of financial funds (Chen et al., 2009). ROI (Return on Investment), represented by revenue scaled by total asset, measures the effectiveness of the firm's use of its total tangible and intangible assets (Reilly and Brown, 2011). Size is measured by the natural logarithm of a firm's total assets and may increase the new debt-issuing capacity, favoring internationalization financing. In addition, larger firms have more availability of capital and human resources, which are essential to identify opportunities in new markets (Barroso et al., 2011). R\&D investment is represented by $R \& D$ expenditure scaled by total sales to compute the R\&D-to-sales ratio (Greve, 2003). When compared to the absolute amount of R\&D expenditure, the R\&D-to-sales ratio controls for the size effect and heteroscedasticity and constitutes a proxy of a firm's effort to innovation (Chen and Hsu, 2009). Family ownership is measured as the number of shares held by a family divided by total shares outstanding (Villalonga and Amit, 2006). The numerator is calculated as the sum of family personal ownership and family listed and unlisted business shareholding. State ownership is represented by the ratio of the number of shares held by the state to the number of total shares outstanding and symbolizes the degree to which the state participates in the business (Wang et al., 2012).

\subsection{Empirical Results}

Table 1 shows the descriptive statistics and Pearson correlations. On average, export intensity is 55.14, independent directors is 0.41 , CEO duality is 0.30 , and board size is 10.06 .

Table 2 contains the results of the OLS regression analysis. Model 1 reports a statistically significant association between export intensity and the following control variables: leverage $(b=-0.29 ; p<0.01)$, size $(b=2.15 ; p<0.10)$, and $R \& D(b=3.15 ; \mathrm{p}<0.01)$.

Model 2 represents the regression model to test $H I$ and, therefore, to test whether a greater fraction of independent directors affects export intensity in a positive way. The regression result demonstrates that the ratio of independent directors is positive and significant $(\mathrm{b}=8.71 ; \mathrm{p}<0.05)$. Therefore, the result supports $H 1$, which proposes that a greater percentage of independent directors positively influences export intensity. The following control variables show significant coefficients: $R \& D(b=2.99 ; p<0.01)$, leverage $(b=-0.33 ; p<0.01)$, and size $(b=1.79 ; p<0.05)$.

Model 3 constitutes the regression model to test $H 2$, which formulates a negative effect of CEO duality on export intensity. The coefficient for CEO duality is not statistically significant; therefore, $H 2$ is not supported. The following control variables show significant coefficients: $R \& D(b=3.15 ; p<0.01)$, leverage $(b=-0.28 ; p<0.01)$, and size $(b=$ $2.30 ; \mathrm{p}<0.05)$.

Model 4 represents the model to test $H 3 a$ and $H 3 b$, which indicate, respectively, that the greater number of directors may have a positive and negative effect. The result shows that the coefficient of board size is negative and significant $(b=-1.35 ; \mathrm{p}<0.01)$. Hence, board size negatively affects export intensity, lending support to $H 3 b$, which points out disadvantages associated to a great number of directors. The following control variables show significant coefficients: $R \& D(b=3.11 ; p<0.01)$, leverage $(b=-0.29 ; p<0.01)$, size $(b=3.20 ; p<0.01)$, and state $(b=-0.29 ; p<0.10)$.

\section{Discussion and Conclusion}

The first result of the empirical analysis is that a greater ratio of independent directors positively affects export intensity. This phenomenon may be explained by the fact that non independent directors and, more specifically, inside directors may face some problems in formulating objective counsel and advising. In the Italian context, where listed firms are often controlled by a large shareholder, agency conflicts may emerge between the latter and minority shareholders. Particularly, top-managers may decide to allocate financial resources into projects that give advantages to the controlling owner and do not generate any value for outside investors. Because inside directors have no incentive to contrast top-manager or majority shareholders, they generally express opinions in line with the latter, generating an expropriation risk for minority shareholders. Independent directors may represent a shelter able to limit top managers' opportunistic behaviors, stimulating them to undertake investments that generate value for all the firms' shareholders, such as those in internationalization. 
This article also finds that board size negatively affects export intensity. The finding is consistent with the perspective that greater board fractionalization may emerge and, consequently, holding divergent perspectives together becomes difficult. Divergence in opinions may make slow the board activities or paralyze them and, therefore, jeopardize the CEO decision-making, relative to internationalization projects. Expansion strategies into other countries may be undermined by inefficient board working.

The main contribution of this article is to enrich the corporate governance literature, highlighting that some board's attributes influence firms' internationalization degree within a majority shareholder system. In fact, most of the studies analyzing the relationship between board of directors and a firm's strategic choices are conducted with regard to firms with a pulverized ownership structure. The second contribution is to extend the internationalization literature providing evidence with regard to a corporate governance antecedent.

This article presents several implications for shareholders and policymakers. In fact, minority shareholders should be more aware of the positive impact that independent directors have on a firm's internationalization degree and, therefore, for its competitiveness. Moreover, institutional investors interested in financing a firm's growth should be careful to the independence of the firm's board. The findings of this article confirm the advice indicated by policymakers, regarding the adequate number of outside and independent directors sitting on the firm's board. Therefore, authority should be aware of the effectiveness of the rule that makes the board more independent.

However, this article is not free from limitations. Firstly, the relationship between board of directors and firms' internationalization is investigated within one national context. Italian firms are featured by concentrated ownership. Therefore, generalizing results of this article should be done with caution. Overall, it is important to warn scholars against extending these findings to other contexts. Future studies should contain cross-country analyses. Secondly, this article is based on a short time period, from 2010 to 2013. In addition, the period considered is influenced by the global financial crisis at the end of 2000. Therefore, further analysis might focus on a longer time span.

An extension of this article would be represented by analyzing the moderating effect of two main categories of two main majority shareholders in the Italian context (i.e., family and state) on the relationship between export and board of directors. In addition, the moderating effects of other categories (e.g., banks, venture capitalists, or pension funds) may be taken into account. Future studies should take into account other variables associated with internationalization, such as foreign direct investment or joint venture.

\section{References}

Aktas, N., Panayiotis, C., Andreou, I., and Karasamani, D. P. (2018). CEO Duality, Agency Costs, and Internal Capital Allocation Efficiency. British Journal of Management. 30(2). 473-493.

Alegre, J., Pla-Barber, J., Chiva, R., and Villar, C. (2012). Organisational learning capability, product innovation performance and export intensity. Technology Analysis and Strategic Management. 24(5). 511-526.

Aulakh, P., Kotabe, M., and Teegen, H. (2000). Export strategies and performance of firms from emerging economies: Evidence from Brazil, Chile, and Mexico. Academy of Management Journal. 43(3). 342-361.

Baliga, B. R., Moyer, R. C., and Rao, R. S. (1996). CEO duality and firm performance: What's the fuss? Strategic Management Journal. 17(1). 41-53.

Barroso, C., Villegas, M. M., and Perez-Calero, L. (2011). Board influence on a firm's internationalization. Corporate Governance: An International Review. 19(4). 351-367.

Bianco, M., and Casavola, P. (1999). Italian corporate governance: effects on financial structure and firm performance. European Economic Review. 43(4). 1057-1069.

Bigelli, M., and Mengoli, S. (2004). Sub-Optimal acquisition decision under a majority shareholder system. Journal of Management and Governance. 8. 373-405

Bird, A., Buchanan, R., and Rogers, P. (2004). The seven habits of an effective board. European Business Journal. 16(3). 128-135.

Calabrò, A., Torchia, M., Pukall, T., and Mussolino, D. (2013). The influence of ownership structure and board strategic involvement on international sales: The moderating effect of family involvement. International Business Review. 22(3). 509-523

Chen, Y. U., Huang, Y. L., and Chen, C. N. (2009). Financing constrains, ownership control and cross-border M\&As: evidence from nine east Asian economies. Corporate Governance: An International Review. 17(6). 665-680.

Chen, H. L., and Hsu, W. T. (2009). Family ownership, board independence, and R\&D investment. Family Business Review. 22(4). 347-362.

Chen, H. L. (2011). Does board independence influence the top management team? Evidence from strategic decisions toward internationalization. Corporate Governance: An International Review. 19(4). 334-350. 
Chen, H. L., Hsu, W. T., and Chang, C. Y. (2016). Independent directors' human and social capital, firm internationalization and performance implications: An integrated agency-resource dependence view. International Business Review. 25(4). 859-871.

Chen, H. S. (2012). Board characteristics and R\&D investment: Evidence from Taiwan's electronics industry. Advances in Management \& Applied Economics. 2(4), 161-170.

Consob. (2018). Report on corporate governance of Italian listed companies. Rome: Commissione Nazionale per le Società e la Borsa.

Daily, C. M., and Dalton, D. R. (1997). Separate, but not independent: Board leadership structure in large corporations. Corporate Governance: An International Review. 5(3). 126-136.

Dalton, D. R., Hitt, M. A., Certo, S. T. , and Dalton, C. M. (2008). The fundamental agency problem and its mitigation: Independence, equity, and the market for corporate control. In J. P. Walsh \& A. P. Brief (Eds.), Annals of the Academy of Management (Vol. 1). 1-64. New York: Lawrence Erlbaum.

Davis, J. H., Schoorman, F. D., and Donaldson, L. (1997). Toward a stewardship theory of management. The Academy of Management Review. 22(1). 20-47.

Donaldson, L., and Davis, J. H. (1991). Stewardship Theory or Agency Theory: CEO Governance and Shareholder returns. Australian Journal of Management. 16. 49-64

Duru, A., Iyengar, R. J., and Zampelli, E. M. (2016). The dynamic relationship between CEO duality and firm performance: The moderating role of board independence. Journal of Business Research. 69(10). 4269-4277

Fama, E., and Jensen, M. C. (1983). Separation of ownership and control. Journal of Law and Economics. 26(2). 301325.

Faccio, M., and Lang, L. H. P. (2002). The ultimate ownership of western European corporations. Journal of Financial Economics. 65(3). 365-395.

Faleye, O., Hoitash, R., and Hoitash, U. (2011). The costs of intense board monitoring. Journal of Financial Economics. 101(1), 160-181.

George, G., Wiklund, J., and Zahra, S. A. (2005). Ownership and the internationalization of small firms. Journal of Management. 31(2). 210-233.

Goodstein, J., Gautam, K., and Boeker, W. (1994). The effects of board size and diversity on strategic change. Strategic Management Journal. 15(3). 241-250.

Goyal, V. K., and Park, C. W. (2002). Board leadership structure and CEO turnover. Journal of Corporate Finance. 8(1). 49-66.

Greve, H. R. (2003). A behavioral theory of R\&D expenditures and innovations: Evidence from shipbuilding. Academy of Management Journal. 46(6). 685-702.

Hackman, J. R. (2002). Leading teams: Setting the stage for great performances. Boston: Harvard Business School Press.

Haynes, K. T., and Hillman, A. (2010). The effect of board capital and CEO power on strategic change. Strategic Management Journal. 31(11). 1145-1163.

Haunschild, P. (1993). Interorganizational imitation: The impact of interlocks on corporate acquisition activity. Administrative Science Quarterly. 38(4). 564-592.

Herrmann, P., and Datta, D. K. (2005). Relationships between top management team characteristics and international diversification: An empirical investigation. British Journal of Management. 16(1). 69-78.

Hillman, A. J., and Dalziel, T. (2003). Boards of directors and firm performance: Integrating agency and resource dependence perspectives. Academy of Management Review. 28(3). 383-396.

Huse, M. (2011).The Value Creating Board. Corporate Governance and Organizational Behaviour, Routledge, Taylor \& Francis Group.

Jensen, M. C., and Meckling, W. H. (1976). Theory of the firm: Managerial behavior, agency costs and ownership structure. Journal of Financial Economics. 3(4). 305-360.

Jensen, M. C. (1993). The Modern Industrial Revolution, Exit, and the Failure of Internal Control Systems. Journal of Finance. 48(3). 831-880.

Johanson, J., and Vahlne, J. E. (1977). The internationalization process of the firm - A model of knowledge development and increasing foreign market commitments. Journal of International Business Studies. 8(1). 2332.

Johanson, J., and Vahlne, J. E. (2009). The Uppsala internationalization process model revisited: From liability of foreignness to liability of outsidership. Journal of International Business Studies. 40. 1411-1431.

Krause, R., and Semadeni, M. (2013). Apprentice, departure, and demotion: an examination of the three types of CEOboard chair separation. Academy of Management Journal. 56(3). 805-826. 
Kor, Y. Y. (2006). Direct and interactive effects of top management team and board compositions on R\&D investment strategy. Strategic Management Journal. 27(11). 1081-1099.

Lai, J. H., Chen, L. Y., and Chang, S. C. (2012). The board mechanism and entry mode choice. Journal of International Management. 18(4). 379-392.

La Porta, R., López de Silanes, F., Shleifer, A., and Vishny, R. (2000). Investor protection and corporate governance. Journal of Financial Economics. 58(1). 3-27.

Lipton, M., and Lorsch, J. (1992). A modest proposal for improved corporate governance. The Business Lawyer. 48(1). 59-77.

Machold, S., Huse, M., Minichilli, A., and Nordqvist, M. (2011). Board leadership and strategy involvement in small firms: A team production approach. Corporate Governance: An International Review. 19(4). 368-383.

Munoz-Bullon, F., and Sanchez-Bueno, M. J. (2011). The Impact of family involvement on the R\&D intensity of publicly traded firms. Family Business Review. 24(1). 62-70.

Nielsen, S. (2010). Top management team internationalization and firm performance. The mediating role of foreign market entry. Management International Review. 50. 185-206.

Papadopoulos, N., and Martin, O. M. (2010). Toward a model of the relationship between internationalization and export performance. International Business Review. 19(4). 388-406.

Pfeffer J., and Salancik G. R. (1978). The external control of organizations: A Resource Dependence Perspective. New York: Harper and Row.

Pugliese, A., Bezemer, P. J., Zattoni, A., Huse, M., Van den Bosch, F. A. J., and Volberda, H. W. (2009). Boards of directors' contribution to strategy: A literature review and research agenda. Corporate Governance: An International Review. 17(3). 292-306.

Reilly, F. K., and Brown, K. C. (2011). Investment Analysis and Portfolio Management. Southwestern: Cengage Learning.

Rivas, J. L. (2012). Diversity \& internationalization: The case of boards and TMT's. International Business Review. 21(1). 1-12.

Ruigrok, W., Peck, S. I., and Keller, H. (2006). Board characteristics and involvement in strategic decision making: Evidence from Swiss companies. Journal of Management Studies. 43(5). 1201-1226.

Rutherford, M., and Buchholtz, A. K. (2007). Investigating the relationship between board characteristics and board information. Corporate Governance: An International Review. 15(4). 576-584.

Ruzzier, M., and Antoncic, B. (2007). Social capital and SME internationalization: an empirical examination. Transformation in Business and Economics. 6(1). 122-138.

Sanders, W. G., and Carpenter, M. A. (1998). Internationalization and firm governance: The roles of CEO compensation, top team composition, and board structure. Academy of Management Journal. 41(2). 158-178.

Shleifer, A., and Vishny, R. W. (1997). A survey of corporate governance. Journal of Finance, 52(2), 737-783.

Thomas, D.E., and Eden, L. (2004). What is the shape of multinationality performance relationship? Multinational Business Review. 12(1). 89-110.

Villalonga, B., and Amit, R. (2006). How do family ownership, control and management affect firm value? Journal of Financial Economics. 80(2). 385-417.

Wang, C., Hong, J., Kafouros, M., and Wright, M. (2012). Exploring the role of government involvement in outward FDI from emerging economies. Journal of International Business Studies. 43(7). 655-676.

Zahra, S. A. (2003). International expansion of US manufacturing family businesses: the effect of ownership and involvement. Journal of Business Venturing. 18(4). 495-512.

Yermack, D. (1996). Higher market valuation of companies with a small board of directors. Journal of Financial Economics. 40(2). 185-211.

Zahra, S. A., and Pearce II, J. A. (1989). Boards of directors and corporate financial performance: A review and integrative model. Journal of Management. 15(2). 291-334.

Zona, F. (2016). Agency models in different stages of CEO tenure: The effects of stock options and board independence on R\&D investment. Research Policy. 45(2). 560-575.

Zona, F, Minichilli, A., and Zattoni, A. (2011). Boards of directors and firm innovation: An empirical analysis on large Italian companies in Huse, M. (edited by), The Value Creating Board. Corporate Governance and Organizational Behaviour, Routledge, Taylor \& Francis Group. 